\title{
Jakominov Mali cerkveni slovar
}

\author{
Andreja Legan Ravnikar
}

Dušan Jakomin, Mali cerkveni slovar, Trst: samozaložba, 2008, 116 str.

V prispevku je predstavljen poljudni slovar katoliškega izrazja Dušana Jakomina, ki je dobrodošel strokovni priročnik za slovenske vernike in laično javnost. Na strnjen in pregleden način razlaga osnovne pojme, povezane s katoliško veroizpovedjo in Cerkvijo kot ustanovo. Vsebuje predvsem liturgično in svetopisemsko, deloma pa tudi cerkvenoupravno in teološko izrazje.

\section{Jakomin's Mali cerkveni slovar (Small Church Dictionary)}

This article presents the Mali cerkveni slovar (Small Church Dictionary), a general dictionary of Catholic terminology by Dušan Jakomin. It will be a welcome professional guide for both Slovenian churchgoers and the general public. It concisely and clearly explains the basic concepts connected with the Catholic faith and the institution of the Church. It is especially rich in liturgical and Biblical expressions, and also includes a selection of terminology connected with church administration and theology.

0.1 Leta 2008 je primorski duhovnik, kulturni delavec, etnograf, publicist in urednik Novega glasa Dušan Jakomin v samozaložbi izdal slovarček slovenskega katoliškega izrazja Mali cerkveni slovar. Izid knjige, ki je izšla v precejšnji nakladi 2500 izvodov, je podprl Urad Vlade Republike Slovenije za Slovence v zamejstvu in po svetu. Petinosemdesetletni duhovnik že od leta 1953 skrbi za slovenske vernike v Škednju (Ščedni) na italijanski strani meje. Slovenisti ga poznamo predvsem kot avtorja Narěnega slovarja Sv. Antona pri Kopru (1995), za katerega je gradivo zbral sam na terenu in ga tudi uredil.

0.2 Praktične potrebe so Jakomina gnale, da je izdal poljuden strokovni slovar, ki zajema izrazje s cerkvenega in verskega področja, izrazje, ki ga slovenski verniki srečujejo pri verskih obredih, katehezi, ob prebiranju verskih besedil ali pri predavanjih o verskih vprašanjih. Knjiga vsebuje sodobno slovensko izrazje, dopolnjeno $\mathrm{z}$ novostmi iz liturgije in cerkvenih obredov od drugega vatikanskega koncila (1962-1965) dalje. Kot navaja avtor v uvodni besedi, je želel potešiti zanimanje za razumevanje pojmovne vsebine domačih krščanskih terminov, prevzetih terminov iz aramejščine, hebrejščine, grščine ali latinščine ter najpogostejših krajšav. Knjigo je Jakomin namenil tudi laični javnosti, kajti »[r]azvejanost verskih pojmov in 
obširnost besedišča nista izziv samo za vernega bralca, ampak tudi za oddaljenega opazovalca. Cerkev kot del civilne družbe ne more ne biti upoštevana.« (Str. 5)

0.3 Večina terminov sega na različna področja, povezana s katoliško veroizpovedjo in ustanovo Cerkve. Največ je osnovnega izrazja - liturgičnih ali obrednih terminov, kamor lahko prištevamo poimenovanja za bogoslužna opravila: molitve, maše, pridige (npr. devétdnévnica 'devetdnevna duhovna priprava na cerkveni praznik'); za bogoslužne predmete: obleka, posoda, knjige (npr. efód 'del duhovniške oprave, najverjetneje predpasnik'); bogoslužne prostore (npr. zakristíja 'prostor, navadno ob oltarnem delu cerkve, za shranjevanje oblek in svetih posod' in 'kraj, kjer se duhovnik s pomočniki pripravi na obrede'); za dobe cerkvenega leta: praznike (npr. vnebovzétje 'zapovedani praznik 15. avgusta'); zakramente cerkve (npr. kŕst 'prvi zakrament vere; oblivanje z vodo in besedami: »... jaz te krstim v imenu Očeta in Sina in Svetega duha«'; kŕst krví 'mučeništvo za Kristusa, velja kot zakramentalni krst'); ljudske pobožnosti (npr. krížev pót 'pobožnost ob štirinajstih postajah, navadno v cerkvi, v spomin na Kristusovo trpljenje in smrt'). Slovar zajema tudi osnovne izraze, ki razlagajo katoliški verski nauk: sveta trojica, greh, trpljenje, spoved, milost, odpuščanje itd., npr. kesánje 'iskreno obžalovanje storjenih grehov ali opuščenih dobrih del; kes'. Razložena so nekatera svetopisemska lastna imena: poimenovanja svetopisemskih oseb (npr. Matúzalem 'hebrejski biblijski očak, Noetov ded, ki mu pripisujejo zelo visoko starost - 969 let, simbolični pomen') in krajev (npr. Jórdan 'glavna reka v Palestini, ki nastane iz več izvirov na gori Hermon in teče skozi Galilejsko (Genezareško) jezero v Mrtvo morje; Jezusov krst v Jordanu'). Manj je svetopisemskih občnoimenskih besed, npr. makabéjci 'judovski bojevniki za svobodo, tudi družina Juda Makabejca', metanója v Stari zavezi 'pokora' in v Novi zavezi 'dejansko spreobrnjenje'. Med cerkvenoupravnim izrazjem najdemo poimenovanja za cerkveno hierarhijo in osnovne dejavnosti, npr. ekskardinácija 'premestitev duhovnika ali drugega klerika iz matične škofije v novo'. Posamezne iztočnice so teološki izrazi, npr. zapóvedi 'deset zapovedi, ki jih je Bog izročil človeku po Mojzesu na gori Sinaj’, celo filozofski izrazi, npr. majévtika 'filozofska doktrina', metempsihóza 'filozofski nazor'. Poleg katoliških je Jakomin zajel posamezne besede iz drugih krščanskih cerkva in verstev, npr. akáthistos 'himna v bizantinski liturgiji, katero molijo stoje'. Krščanski (katoliški) termini se po področjih rabe deloma prekrivajo.

0.4 Avtor razkriva svoj regionalni izvor v želji, da bi bralec razširil znanje o cerkveni kulturi, ki izhaja iz sredozemskega prostora, kjer se zahodna latinska tradicija stika z vzhodno. Njegov izvor se kaže tudi v avtorjevem izboru iztočnic za predstavitev v geselskem članku, npr. konfín (it.) db. 'meja; [...] mesta v Italiji, kamor so $\mathrm{v}$ času prihoda italijanske oblasti v slovenske kraje, predvsem v času fašizma, pošiljali duhovnike, izobražence ali vidnejše osebe daleč od svojega domačega kraja, da bi onemogočili njihov vpliv'. Aktualen zgled iz današnjega časa je geselski članek džíhad (arab.) 'sveta vojna'. 
0.5 Dušan Jakomin se je opiral predvsem na gradivske vire, ki jih je v uvodni besedi (str. 5-6) posebej navedel. To so rubrika Kaj pomeni Silvestra Čuka, ki je izhajala v reviji Ognjišče v letih 1975-1980, Leksikon duhovnosti Vladimirja Truhlarja (1974), Liturgika Marijana Smolika (1995) in Leksikon ikonografije, liturgike $i$ simbolike zapadnog kršćanstva i Uvod u ikonologiju (Jakomin ima ikonografiju) Anđelka Badurina in Radovana Ivančevića (1985). Iz bibliografije na koncu knjige (str. 115-116) izvemo, da se je zgledoval po slovarjih sosednjih narodov, npr. pri hrvaškem z naslovom Mali religijski riječnik (2006) Adalberta Rebića in italijanskem Dizionario liturgico-pastorale Antonia Mistroriga (1977).

\section{Glava in zaglavje geselskega članka}

1.1 Na dobrih stotih straneh prinaša Mali cerkveni slovar okrog 1500 geselskih člankov (na stran v povprečju torej 13-15 gesel), ki so večinoma kratki in zgoščeni (2-3 vrstice). Nekoliko obsežnejša so gesla z več pomeni, z dodanimi splošnimi pomenkami ali razlagami cerkvenozgodovinskih in etimoloških okoliščin. Krepko natisnjene iztočnice, ki so razvrščene po abecednem zaporedju, so lahko enobesedne ali večbesedne. Besedni red pri večbesednih se je oblikoval glede na prvo črko prve besede v zvezi, kar je največkrat pridevnik levoprilastkovnih besednih zvez. Iztočnice so večinoma občnoimenske, znotraj njih je občuten delež prevzetih strokovnih izrazov (internacionalizmi). Od lastnih imen so zajeta svetopisemska osebna in zemljepisna imena. Posamezne iztočnice so (pretežno) latinski citati, npr. Códex iúris canónici CIC (lat.), Dominús vobíscum (lat.), Eloí, Eloí, lemá sabahtáni? (aram.). Pred pomenskim delom slovarskega sestavka, ki ga uvaja okrajšava db. (= dobesedni prevod), je dobrodošla odločitev, da je pri latinskih citatih v oglatem oklepaju naveden izgovor, npr. [kódeks júris kanónici], [dóminus vobískum]. Geselski članek se po potrebi členi s podiztočnicami - stalnimi besednimi zvezami, t. i. terminološkimi besednimi zvezami; tako npr. iztočnici bogoslužje sledi definicija, v nadaljevanju pa avtor niza podiztočnice besedno b.[ogoslužje], evharistično b.[ogoslužje], spokorno b.[ogoslužje] in b.[ogoslužje] božje besede.

1.2 Med iztočnicami po pričakovanju prevladujejo samostalniki in samostalniške besedne zveze, le redki so zgledi samostalniško rabljenih pridevnikov (Brezmádežna, Najsvetéjše) in glagolov (pokadíti, zaspáti). Več je glagolskih samostalnikov znotraj večbesednih terminov, npr. lómljenje krúha, priprávljanje daróv, tŕkanje na pŕsi, vstajênje mesá, zedínjenje kristjánov. Pridevnikov kot samostojnih iztočnic ni, čeprav bi jih pričakovali vsaj pri najpogostejših terminih, kot so božji, gospodov, sveti. Izjemoma uvršča zvezo v abecedni red iztočnic tudi predlog, npr. pód obéma podóbama (tako onaglašuje Jakomin).

1.3 Avtor ne navaja niti večine slovničnih (npr. pregibanje, besednovrstnost) niti besedotvornih podatkov, dobimo pa podatek o naglasu. Onaglašenost iztočnic je zlasti pri citatnih terminih in izrekih zelo koristna. Ponekod avtor ni prepoznal kvalitete naglašenega samoglasnika (ozki, široki $o, e$ ), zato je ostrivec tudi na 
mestu, kjer je v knjižni normi zapisana strešica (rod. mn. darôv). Kratko naglašenega samoglasnika ni vedno pravilno označil, npr. bôžji grôb namesto bôžji gròb, brát láik namesto bràt láik.

1.4 Poimenovanja božjih oseb in nadomestnih imen zanje se zapisujejo $\mathrm{z}$ veliko začetnico kot $\mathrm{v}$ teoloških in bogoslužnih besedilih, npr. Bóg (v razlagalnem delu gesla Bóg je izrecno povedano, da ime vedno pišemo z veliko začetnico, če se nanaša na Božjo osebo oz. na krščanskega Boga), Sveti Duh (ni samostojno geslo, omenja se njegova vloga pri birmi v geslu bírma), Dôbri pastír, Mesíja, Trojíca, Odrešeník (niso pa izkazana samostojna gesla z iztočnicami Stvarnik, Križani, Vsemogočni). Privzdignjeno držo spoštovanja izkazuje tudi zapis z veliko začetnico najpogosteje rabljenih pridevnikov: Božji, Gospodov, Sveti. Jakomin jih zapisuje nedosledno, odvisno od razsežnosti pomenskega prenosa, npr. Bôžja obljúba, Bôžje kraljéstvo, Bôžje ljúdstvo, Bôžje usmíljenje itd., toda bôžja pót, bôžji grôb. Ime svetopisemskega dogodka in praznika (kot tudi drugih praznikov) je zapisano z malo začetnico, npr. svéti tríje králji; v SP 2001 je osebno ime Sveti trije kralji zapisano z veliko. Jakomin piše z veliko začetnico nekatere temeljne pojme krščanske vere, npr. Najsvetéjše, Gospodova molitev 'temeljna krščanska molitev, očenaš' v geslu Ôče náš (prim. róžni vênec 'katoliška ljudska molitev Jezusu in Mariji v čast'), svéto Réšnje teló. Primer iztočnic razodétje 'dejanje, s katerim se Bog razodeva človeku, odnos med človekom in Bogom' in Razodétje 'novozavezna preroška zadnja knjiga Svetega pisma, imenovana tudi Apokalipsa' potrjuje pomensko razločevalnost velike začetnice.

1.5 Znak > 'glej tudi' (str. 7) ima vlogo vodilke, ki povezuje in opozarja bralca na pomensko ali kako drugače sorodne besede, obravnavane $\mathrm{v}$ drugih geslih. Vodilka je navedena na koncu geselskega članka za razlagalnim in ponazarjalnim delom, npr. meníh >manastir, samostan, monah (takoj za znakom > so besede neonaglašene), izpraševánje vestí $>$ vest, ali povsem samostojno, npr. desét Bôžjih zapôvedi $>$ dekalog; >Postava; >Sinaj. Na ta način avtor pojasnjuje nekatera sopomenska razmerja med iztočnicami, npr. stólnica $>$ katedrala, prídiga $>$ homilija. $Z$ vodilkami, ki praviloma niso obojesmerne, se geselski članki med seboj pomensko dopolnjujejo, res pa se občasno določeni podatki tudi podvajajo.

\section{Razlagalni in ponazarjalni del geselskega članka}

Jakomin je na poljuden način, vendar zgoščeno in pomensko precizno predstavil pomensko ravnino osnovnega krščanskega izrazja.

2.1 Glede na izvor ločimo domače, prevzete in citatne iztočnice. V izboru iztočnic prevzeto izrazje močno prevladuje nad domačim, kar pa ne odraža njunega dejanskega razmerja v (prevladujoče zajetem) liturgičnem izrazju. Avtor jih je verjetno izbral, ker je pomen teh terminov teže razbrati, zato so vernikom ostajali nerazumljivi ali pa so se ti zavedali le njihove približne pomenske vrednosti. V 
današnji rabi so prevzeti krščanski termini povsem prilagojeni jezikovnim zakonitostim slovenskega jezika, npr. lekcionár (lat.) 'bogoslužna knjiga, v kateri so zbrana mašna berila, evangelij, psalmi, posebej določeni za vsak dan in razvrščeni po redu cerkvenega leta', litúrgika (gr., lat.) 'nauk o bogoslužnih obredih'. Kjer raba niha, so se oblikovali variantni prevzeti izrazi, med katerimi se ustvarja hierarhično razmerje, kar je avtor tudi zabeležil, npr. madrása tudi medrésa (arab.).

2.2 Tudi citatne verske izraze je avtor pomensko analiziral: poleg verskega pomena je navedel tudi splošni pomen. V okroglem oklepaju je zapisal izvorni jezik ali jezik posrednika, npr. faldistórij (nem.) ‘premakljivi škofov sedež pri obredih'. Manj je zgledov za enobesedno iztočnico, npr. Exúltet (lat.) [ekzúltet] db. 'veseli se; hvalnica, začetna beseda velikonočne hvalnice pri bdenju na velikonočno soboto'; ex cáthedra (lat.) [éks kátedra] db. 's stola; nezmotno versko ali moralno papeževo učenje, kadar govori kot najvišji pastir Cerkve; govoriti z avtoriteto'; Katholíkentág (nem.) 'zborovanje nemških katoličanov'. Pogosteje so izpričane stalne besedne zveze, izreki in znani citati, ki so lahko cele povedi, npr. níhil óbstat quóminus imprimátur (lat.) [níhil óbstrat kvóminus imprimátur] db. 'nič ne nasprotuje za natis; tiskana opomba uradnega cenzorja, da ni ovir za tiskanje določene knjige ali publikacije o verskih in moralnih zadevah'.

2.3 Geselski članki z domačim krščanskim izrazjem so na prvi pogled manj opazni, vendar nič manj koristni, saj se je Jakomin zavedal, da tudi verniki nemalokrat poznajo pomene osnovnih verskih pojmov le približno. Prevladujejo liturgični in svetopisemski izrazi, med katerimi so tudi simboli. Naj naštejemo nekaj tovrstnih iztočnic: obljúba 'trden sklep, zvestoba v nekem dogovoru ali stvari', obrezovánje, občéstvo, občéstvo svetníkov, očítanja, mesó, mír, mílost, sôdba bôžja, spoznaválec 'svetnik, ki ni umrl mučeniške smrti', spregléd (namesto spreglèd), srcé, ólje, pelikán, ríba (monogram IHTIS), sídro, vôda, štíri, sédem, tŕkanje na písi, víno, vstajênje mesá, zádnja večérja, zaobljúba, zapóvedi (namesto zapôvedi), zaspáti ‘biblijski izraz za umreti', zavétnik, zavéza, zláto têle, zvelíčanje, zvón, zorníce. Pogrešamo nekatere katoliške termine, npr. živi - mrtvi, bližnji, božanstvo, čast, čistost, dedič (nebeškega kraljestva), dobra dela, dolg, dolžnik, Gospod, grešnik, grešnica, izvoljenec, kazen, ljubezen, muka, nebeško kraljestvo, obhajilo, oklici, opomin, opravičenje, pobožen, pravica, skušnjava, služabnik, smrt, telo, upanje, usmiljenje, zahvala. Malo je zgledov tvorjenk s predponskim obrazilnim morfemom ne-, ki se pogosto uporabljajo, npr. nepokora, nemilost, nevera.

Pomenk pri večpomenskih terminih avtor ni oštevilčil, temveč jih je znotraj geselskega članka ločil s podpičjem, kar včasih deluje nepregledno. S podpičjem je namreč ločil tudi dobesedni prevod, dodatne (zgodovinske, etimološke, kulturološke) razlage, citate iz Svetega pisma, konkretne zglede v besedilu, sopomenke in pomensko sorodne besede. Poglejmo si zgled tovrstnega geselskega članka: »škof episkop (gr.) db. nadzornik; cerkveni predstojnik; tudi tretja stopnja zakramenta svetega reda: škofovsko posvečenje; škof ordinarij; šele proti koncu 1. st. po Kr. srečamo zarodke kasnejšega monarhičnega episkopata in jasnejše razčlenitve cerkvenih služb; >episkop, ordinarij, sufragan«. Ponekod je dodal tudi splošni pomen 
(v ležečem tisku): »nebésa v krščanstvu stanje, kraj, kjer prebivajo Bog in zveličani; veliko ugodje ali velika sreča; nebeški duhovi: angeli in duše v nebesih«.

2.4 Da je med krščanskimi termini veliko večbesednih izrazov, nam dokazujejo tudi mnoge večbesedne iztočnice $\mathrm{v}$ Jakominovem slovarju. Po pričakovanju prevladujejo levoprilastkovne zveze s samostalnikom v odnosnici, ki se razvrščajo po abecednem redu prvega izraza $v$ zvezi, torej pridevnika. Kot iztočnice so pogosto navedene stalne besedne zveze s starinskim svojilnim pridevnikom božji, ki žal nima samostojne razlage, npr. Bôžja beséda, Bôžja prevídnost, Bôžja rôka, Bôžja vólja, Bôžje kraljéstvo, Bôžje ljúdstvo, Bôžje okó, Bôžje posinôvljenje, Bôžje usmíljenje, bôžji grôb (namesto gròb). Tudi pridevnik sveti je izpričan v več iztočnicah, ne pa kot samostojna enota, npr. Svéta dežêla, Svéti ôče, svéti pŕt, Svéti sédež, svéti sinód, svéti šôtor, svéti tríje králji, svéti večér, svéto léto, svéto Réšnje teló. Zgled »družína (sveta) družina Jezusa, Marije in Jožefa« razkriva drugačen postopek slovarskega prikaza večbesednih strokovnih izrazov. Izhaja se iz jedrnega dela zveze - samostalnika, ki je enobesedna iztočnica, od tod se tvorijo samostalniške in redkeje glagolske besedne zveze, ki jih avtor prikazuje v okviru istega geselskega članka. Na tretji način je Jakomin predstavil cerkvéno léto >leto cerkveno: »léto (cerkveno) v teku leta cerkev izpolnjuje vzgojo in izobrazbo vernikov, razgrinja celotno Kristusovo skrivnost in obhaja spomin svetniških godov; [...] « Podobno je oblikoval večbesedno iztočnico sôdba Bôžja; drugačen besedni red v slovarju ni izpričan. (Pridevnik na desni strani odnosnice je v pridigarski tradiciji stilno zaznamovan, saj prinaša večjo izrazno in sugestivno moč. Pri prebiranju verskih besedil se je pokazalo, da so zapostavljeno rabljeni pridevniški prilastki, npr. božji in svet, res odraz privzdignjene rabe, vendar so se $\mathrm{v}$ terminološki rabi nevtralizirali (Legan Ravnikar 2008: 111-112).)

Desnoprilastkovnih zvez, za katere je v slovenščini značilen zapostavljeni samostalnik, je občutno manj in so večkrat predložne: dúše $\mathbf{v}$ vícah, posódice za svéta ólja, posvetítev cérkve, priprávljanje daróv, prôšnja nad daróvi, prôšnja po obhajílu, prôšnje vérnikov.

2.5 V slovarju so razvejeno vzpostavljena sopomenska in blizupomenska razmerja med iztočnicami. Naj naštejem nekaj razlikovalnih prikazov sopomenskih krščanskih terminov: »cvétna nedélja ali oljčna nedelja, zadnja nedelja pred veliko nočjo« (prim. »óljčna nedélja cvetna nedelja, nedelja pred veliko nočjo«), »pravosláven ali ortodoksen« (+ razlaga); »núna (lat.) redovnica« (+ razlaga); »stólnica $>$ katedrala« (+ razlaga); »prídiga >homilija« (+ razlaga); »sveto Réšnje teló hostija; >Najsvetejše«.

2.6 Kratice in druge krajšave imajo svoje mesto v sodobnem jeziku verskih in cerkvenih besedil. Uveljavile so se zaradi praktičnosti, kratkosti in nedvoumnosti rabe, npr. »msgr. (lat.): monsinjor (cerkveno odlikovanje)«; »OFM kratica: Órdo Frátrum Minórum (red manjših bratov), uradni naziv za redovnike frančiškanskega reda«; v geslu Códex iúris canónici »CIC (lat.): Códex iúris canónici [kódeks júris kanónici] - zakonik cerkvenega prava $(1917,1984) \ll ;$ v geslu Drúžba 
Jézusova »DJ jezuiti«; »INRI (lat.) kratica: Iésus Nazarénus Réx Iudeórum. Napis na Jezusovem križu, ki pomeni: Jezus Nazarečan, judovski kralj; Poncij Pilat ga je dal napisati v latinščini, grščini in aramejščini na križ nad Jezusovo glavo (Jn 19, 19)《.

3 Če se ozremo na slovar v celoti, je avtor častitljive starosti Dušan Jakomin korektno pripravil poljudni slovar katoliške terminologije, ki smo ga v slovenskem prostoru zelo pogrešali. Delo je bilo zahtevno, terjalo je veliko znanja, izkušenj in potrpežljivosti. Tega našemu rojaku očitno ni manjkalo, zato mu za izid knjige iskreno čestitamo.

\section{Navedenki}

Legan Ravnikar 2008 = Andreja Legan Ravnikar, Slovenska krščanska terminologija: od Brižinskih spomenikov do srede 19. stoletja, 2008, Ljubljana: Založba ZRC, ZRC SAZU (Lingua Slovenica).

SP 2001 = Slovenski pravopis 2001, Ljubljana: SAZU - ZRC SAZU, Inštitut za slovenski jezik Frana Ramovša, 2001. 